\title{
Cytochemical Responses in the Digestive Tissue of Mytilus edulis Complex Exposed to Microencapsulated PAHs or PCBs
}

\author{
P. K. Krishnakumar, ${ }^{1}$ E. Casillas, and U. Varanasi \\ Environmental Conservation Division, Northwest Fisheries Science Center, National Marine Fisheries \\ Service, National Oceanic and Atmospheric Administration, 2725 Montlake Blvd. East, \\ Seattle, WA 98112, U.S.A.; and ${ }^{1}$ Research Centre of Central Marine Fisheries Research Institute, \\ PB No. 244, Bolar, Mangalore 575 001, India
}

\begin{abstract}
Cytochemical responses in the digestive tissue of Mytilus edulis complex fed a microencapsulated mixture of PAHs (composed of phenanthrene, fluoranthene and benzo[a]pyrene) or PCBs (Aroclor 1254) were evaluated. Lysosomal membrane labilization period and lipofuscin content of digestive tissue were significantly decreased and increased, respectively, after 30 days of exposure to PAHs but not PCBs. NADPH-ferrihemoprotein reductase activity in the digestive tissue was significantly increased after 30 days exposure to both PAHs and PCBs, whereas catalase activity was significantly increased only after exposure to PCBs. Neutral lipid content and gamma-glutamyl transpeptidase activity of digestive tissue of mussels were significantly increased and decreased, respectively, after 30 days exposure to both PAHs and PCBs when compared to untreated mussels, but were not significantly different when compared to mussels treated with com oil representing the vehicle control. Exposure to PAHs induced peroxisome proliferation in the digestive tissue of M. edulis complex. The observed cytochemical responses in the digestive tissue of M. edulis complex exposed to PAHs and PCBs in the laboratory are comparable to the cytochemical responses observed in the digestive tissue of mussels collected in the field from sites contaminated with predominantly PAHs and PCBs. сомP вIоснем PHysiol 118C;1:11-18, 1997. (C) 1997 Elsevier Science Inc.
\end{abstract}

KEY WORDS. Biological indicators, cytochemical responses, detoxification enzymes, Mytilus edulis complex, PAHs, PCBs

\section{INTRODUCTION}

Marine bivalves are widely used as sentinel organisms for coastal pollution monitoring programs. A prominent example of this is the United States Mussel Watch program which monitors chemical contaminant levels in marine bivalves, including the blue mussel Mytilus edulis (23). Although sessile organisms such as mussels have proven effective in assessing chemical contaminants in our coastal environments, their potential as indicator species for assessing the biological impact of chemical contaminants has only recently been suggested for use in environmental monitoring $(13,21)$.

Numerous cytochemical and cytological responses have been developed and recommended as potential tests for quantifying and monitoring the environmental impact of xenobiotics in bivalve molluscs (5). Recent field studies

\footnotetext{
Address reprint requests to: E. Casillas, Environmental Conservation Division, Northwest Fisheries Science Center, National Marine Fisheries Service, National Oceanic and Atmospheric Administration, 2725 Montlake Blvd. East, Seattle, WA 98112. Tel. 206-860-3313; Fax 206-860-3335; E-mail: edmundo.casillas@noaa.gov.

Received 25 October 1996; revised 5 April 1997; accepted 8 April 1997.
}

have shown that some of these parameters in mussels can be used to discriminate between polluted and unpolluted sites $(1,6,13,14,27)$. Consistent depression in lysosomal membrane stability, increased NADPH-ferrihemoprotein reductase and catalase activity, and enhanced lipofuscin and neutral lipid accumulation in the digestive tissue were observed in mussels collected from contaminated urbanassociated sites when compared to mussels from reference sites in Puget Sound, Washington $(13,14)$. Relationships between body burden of chemical contaminants and reduced growth and molecular and cellular alterations in the digestive tissue of mussels were identified. However, direct cause-and-effect relationships were difficult to attribute to any single class of chemical contaminant due to the cooccurrence of many of the tissue contaminants. Biological effects associated with bioaccumulation of organic contaminants have been attributed to the uptake of specific compounds and/or metabolites rather than the total body burden of hydrocarbons or chlorinated hydrocarbons (2). Accordingly, mussels were exposed to selected PAHs or to the PCB mixture Aroclor 1254 to understand contaminant specificity of selected cytochemical and cytological re- 
sponses in the mussel, M. edulis complex, and thus their potential as biological indicators of exposure in field-exposed mussels.

\section{MATERIALS AND METHODS}

Mussels (M. edulis complex) were collected from a reference site at Double Bluff in Puget Sound, Washington (10) during low tide. Mussels $(50-60 \mathrm{~mm})$ were cleaned and acclimated for 1 week in unfiltered running sea-water containing natural phytoplankton at an ambient temperature of $9^{\circ} \mathrm{C}$ and salinity of $30 \mathrm{ppt}$.

\section{Microencapsulation}

Selected PAHs and PCBs (as Aroclor 1254) were microencapsulated in a gelatin/acacia gum mixture $(8,29)$. A mixture of PAHs in acetone containing $85.5 \mathrm{mg}$ of phenanthrene, $68.4 \mathrm{mg}$ of fluoranthene, and $17.1 \mathrm{mg}$ of benzo(a) pyrene (ratio of $5: 4: 1-\mathrm{w} / \mathrm{w} / \mathrm{w}$ ) was dissolved in $20 \mathrm{ml}$ of corn oil, heated to $40^{\circ} \mathrm{C}$, and sonicated for $20 \mathrm{~min}$. The $\mathrm{PAH}$ mixture was homogenized with $5 \mathrm{gm}$ of acacia gum and $5 \mathrm{gm}$ of gelatin for $2 \mathrm{~min}$ in a blender at $40^{\circ} \mathrm{C}$ and brought to a final volume of $1 \mathrm{~L}$ with deionized water, also at $40^{\circ} \mathrm{C}$. This emulsion contained $171 \mathrm{mg}$ of PAHs. The emulsion was cooled for $1 \mathrm{hr}$ in icewater to form hardened microencapsulated vessels containing PAHs, and stored refrigerated in sealed containers. Similarly, $171 \mathrm{mg}$ of PCBs (Aroclor 1254) was dissolved in $20 \mathrm{ml}$ of corn oil and microencapsulated as described above. This procedure reportedly gives microcapsules with a diameter of $1-10 \mu \mathrm{m}$, with most of the capsules around $5 \mu \mathrm{m}$ (29).

Forty mussels were randomly dispersed in each of eight 38-L capacity tanks supplied with filtered, running seawater. Mussels in one set of duplicate tanks served as the untreated controls receiving algal food only; mussels in another set of duplicate tanks served as the vehicle controls receiving algal food and microencapsulated corn oil, simultaneously. The third and fourth sets of duplicate tanks served as experimental treatments receiving food and microencapsulated PAHs or PCBs. The sea-water flow in all tanks were maintained $800-1000 \mathrm{ml} \cdot \mathrm{min}^{-1}$ (temperature $9.0 \pm 0.5^{\circ} \mathrm{C}$; salinity $30.0 \pm 0.5 \mathrm{ppt}$, and dissolved oxygen $>90 \%$ saturation). Mussels were fed twice daily with a commercially available concentrated and preserved algal diet consisting of Thalassiosira pseudonana (Coast Oyster Co., Quilcene, WA). The concentration of algae at each feeding period in all tanks was adjusted to approximately $4 \times 10^{3} \mathrm{cells} \mathrm{m}^{-1}$.

The microencapsulated PAHs, PCBs, or corn oil only were added once daily during one of the feeding periods to the respective tanks, to achieve an equivalent final concentration of $150 \mu \mathrm{g}$ contaminant $\cdot \mathrm{L}^{-1}$ sea-water. Just before adding the microencapsulated contaminants, sea-water flow was shut off in all tanks and restarted after $2 \mathrm{hr}$. Our obser- vation in all tanks showed that mussels removed the encapsulated particles within $2 \mathrm{hr}$. Constant and gentle aeration was maintained in all tanks to keep the microencapsulated contaminants and algae in suspension. After 6 and 30 days of exposure, 10 mussels from each treatments were sampled and digestive glands were dissected out for cytochemical analysis. Similarly, 10 mussels were sampled from each treatment for chemical analysis of whole soft tissue.

\section{Tissue Chemistry}

Whole soft tissue samples were dissected out, pooled, and kept at $-80^{\circ} \mathrm{C}$ until analysis. Samples were analyzed for organic chemical contaminants (phenanthrene, fluoranthene, benzo(a)pyrene and PCBs) as described by Sloan et al. (26) and Krahn et al. (12). Polycyclic aromatic hydrocarbons were quantified using gas chromatography (GC) coupled with mass spectrometry (GC/MS) and PCBs were determined using GC coupled to an electron capture detector (GC/ECD). The results were expressed in $\mathrm{ng} \cdot \mathrm{g}$ dry tissue weight ${ }^{-1}$.

\section{Cytochemistry}

A small section of the digestive gland was rapidly removed from each of 10 randomly-selected mussels and placed in a straight rows across the center of cryomolds (Tissue-Tek, Miles Inc. Elkhart, IN) (five tissue samples/mold). Tissue samples were quickly embedded in O.C.T. compound (Tissue-Tek) and super-cooled in hexane precooled to $-70^{\circ} \mathrm{C}$ in liquid nitrogen, and kept at $-80^{\circ} \mathrm{C}$ until analysis. The frozen tissues were sectioned serially at $10 \mu \mathrm{m}$ in a cryostat at $-25^{\circ} \mathrm{C}$. All samples were coded prior to freezing to insure that samples were read blindly and decoded only after all measurements were made. Cryostat tissue sections were stained for $\mathrm{N}$-acetyl $\beta$-hexosaminidase (NAH) to determine lysosomal membrane labilization period (LP) and for neutral lipids (NL) and lipofuscin (LF) content as described earlier $(13,21)$. In addition, tissue sections were stained for NADPH-ferrihemoprotein reductase (NFR), NADH-DT diaphorase (DTD), $\gamma$-glutamyl transpeptidase (GGT), and catalase (CAT) activity as described by Krishnakumar et al. (14). Peroxisome proliferation (PP) was assessed using catalase activity as the marker enzyme as described by Reddy and Lalwani (25). The criteria for PP was an increase in size and/or number of peroxisomes in each digestive tubule stained by the DAB method. Specificity of the DAB method for catalase activity (3) was achieved by using 3-amino1,2,4-triazole as a specific inhibitor of catalase activity, to account for lipofuscin co-staining, a source of potential interference in the method. Whereas CAT activity was measured in terms of pixel density using image analysis, $\mathrm{PP}$ is measured in terms of the area occupied by the digestive tubules reacted for CAT activity. 


\section{Image Analysis}

Activity of NAH, NFR, DTD, GGT, CAT, lysosomal membrane labilization period, and NL and LF content in the tissue sections were quantified using image analysis (13). The image analysis system consists of a high resolution CCD color camera (COHU model 8215.2000) mounted on a light microscope. The image is displayed on a television screen and captured using image analysis software (NIH Image 1.44) on a Macintosh IICX computer. Images were viewed using a $40 \times$ objective. Five images of digestive tubules for each cytochemical analysis were randomly taken from each duplicate section of each mussel tissue. All images for each cytochemical test were captured in one session during which the microscope illumination (powered by a stabilized DC supply) and camera setting were kept constant. The digital image consisted of 8 bit, $320 \times 240$ matrix of picture elements (pixels), where each pixel consisted of a number between 0 and 255 representing the intensity of transmitted light (or gray level) at a point. Stored images were later analyzed to determine the average pixel density of the reaction product in each image as described by Krishnakumar et al. (13).

\section{Statistical Analyses}

Differences in NFR, DTD, CAT, and GGT activities and lysosomal labilization period, NL and LF content in the digestive tissue of mussels among different treatments were tested by analysis of variance (ANOVA). Dunnett's multiple comparison test was used to determine significant differences in cytochemical responses in mussels receiving PAHs or PCBs compared to mussels receiving corn oil only (vehicle control). Findings were considered significant at $\alpha=$ 0.05 .

\section{RESULTS}

\section{Tissue Burden of PAHs and PCBs}

The tissue concentrations of PAHs and PCBs in mussels after 6 and 30 days of feeding microencapsulated contaminants are shown in Table 1. Tissue concentrations of phenanthrene, fluoranthene, benzo(a)pyrene, and PCBs averaged 50, 130, 6, and $490 \mathrm{ng} \cdot \mathrm{g}^{-1}$, respectively, in control mussels. Tissue concentrations of PAHs and PCBs in vehicle control and algal control mussels showed very little variation (Table 1) throughout the 30-day test period. After 6 days of exposure to a select mixture of PAHs, tissue concentration of phenanthrene, fluoranthene, and benzo(a)pyrene increased 10, 7, and 17 times, respectively, compared to control mussels. After 30 days of exposure, tissue concentration of phenanthrene, fluoranthene, and benzo(a)pyrene increased 407, 363, and 943 times, respectively, compared to control mussels. After 6 and 30 days of feeding microencapsulated Aroclor 1254, tissue concentration of PCBs in- creased 2 and 16 times, respectively, compared to control mussels.

\section{Subcellar Structures and Function}

Lysosomal labilization period, lipofuscin and neutral lipid content, and peroxisome proliferation in the digestive tissue of mussels after 6 and 30 days of exposure to PAHs and PCBs are shown in Table 2. A significant reduction in LP was observed in mussels after 6 and 30 days of exposure to PAHs, whereas a significant reduction in LP, with respect to vehicle control mussels, was observed only after 6 days and not 30 days of exposure to PCBs. The LF content in the digestive tissue was significantly increased after 6 days of exposure to PCBs but was no different from vehicle controls after 30 days of exposure, whereas the LF content in $\mathrm{PAH}$ exposed mussels were significantly elevated after 30 days of exposure. The NL content in the digestive tissue of mussels exposed for 6 days to PAHs was significantly elevated with respect to control mussels receiving corn oil, however, this increase was not apparent after 30 days of exposure, primarily because of significantly elevated NL in mussels receiving corn oil during this period. No significant effect of PCBs on the NL content in the digestive tissue was observed. Peroxisome proliferation was relatively high in the digestive tissue of untreated control mussels, however, upon receiving corn oil, peroxisome proliferation was significantly reduced. Peroxisome proliferation was significantly increased in the digestive tissue of mussels after 6 and 30 days of exposure to PAHs, but not PCBs, in comparison to levels observed in the mussels receiving corn oil only.

\section{Detoxifying Enzymes}

Activities of NFR, CAT, DTD, and GGT in the digestive tissue of mussels after 6 and 30 days of exposure are shown in Figs 1 and 2. Catalase and DTD activities were significantly depressed in vehicle control mussels 30 and 6 days into the experiment, respectively, compared to mussels fed algae only. Activities of NFR in the digestive tissue of mussels were significantly increased ( $p \leq 0.05$ ) after 6 and 30 days of exposure to both PAHs and PCBs, compared to vehicle control mussels (Fig. 1a \& b), whereas CAT activity was significantly increased after 30 days of exposure to PCBs only. DTD and GGT activity was significantly increased and decreased, respectively, after 6 days, but not 30 days, of exposure to both PAHs and PCBs compared to vehicle control mussels (Fig. 2a \& b).

\section{DISCUSSION}

Results show that 6 and 30 days of exposure to a mixture of PAHs or PCBs fed at an equivalent concentration of 150 $\mu \mathrm{g} \cdot \mathrm{L}^{-1}$ each day resulted in significant bioaccumulation of 
TABLE 1. The concentration of polycyclic aromatic hydrocarbons (PAHs) and polychlorinated biphenyls (PCBs) in whole tissue of Mytilus edulis complex (ng $\cdot \mathrm{g}^{-1}$ dry tissue weight) after 6 and 30 days of feeding a microencapsulated model mixture of PAHs or PCBs at an equivalent concentration of $150 \mu \mathrm{g} \cdot \mathrm{L}^{-1}$ sea-water. For each treatment, 20 mussels were homogenized to make a uniform composite which was subsampled for chemical analysis. See Materials and Methods for details

\begin{tabular}{|c|c|c|c|c|}
\hline \multirow[b]{2}{*}{ Treatment } & \multicolumn{3}{|c|}{$\begin{array}{c}\text { PAHs } \\
\left(\text { ng }^{-1} \text { dry tissue weight }\right)\end{array}$} & \multirow{2}{*}{$\begin{array}{c}\text { PCBs } \\
\text { (ng g } \text { g }^{-1} \text { dry tissue } \\
\text { weight) }\end{array}$} \\
\hline & Phenanthrene & Fluoranthene & Benzo(a)pyrene & \\
\hline \multicolumn{5}{|l|}{6 Days } \\
\hline Algal control & 43 & 110 & 4 & 320 \\
\hline Vehicle control & 41 & 87 & 5 & 710 \\
\hline PAHs & 430 & 650 & 85 & - \\
\hline PCBs & - & - & - & 1600 \\
\hline \multicolumn{5}{|l|}{30 Days } \\
\hline Algal control & 58 & 150 & 6 & 400 \\
\hline Vehicle control & 59 & 160 & 7 & 540 \\
\hline PAHs & 24000 & 58000 & 6600 & - \\
\hline PCBs & - & - & - & $>8700$ \\
\hline
\end{tabular}

these chemical contaminants, alterations in the lysosomal membrane function, cell content, and induction of some detoxifying enzymes in the digestive tissue of M. edulis complex. After 30 days of feeding the chemical contaminants in a microencapsulated form, the tissue concentration of total PAHs and PCBs increased by nearly 400 and 22 times, respectively, compared to the control mussels. This increase in the tissue concentrations of PAHs or PCBs and the observed biological alterations in the digestive tissue suggests that exposure to PAHs or PCBs was a causative factor in the cellular and subcellular responses, even when alterations caused by the corn oil (the vehicle carrier) were taken into consideration.

Feeding microencapsulated PAHs or PCBs to mussels was used to evaluate the effect of chemical contaminants on cellular and subcellular responses in the digestive tissue without the constraints of additional stresses imposed by other exposure techniques such as the routine technique of repeatedly injecting organic contaminants into the body of bivalves. In addition, administering organic contaminants in a microencapsulated particle form represents a natural way of introducing the contaminants to filter feeding bivalve mulluscs for toxicological investigations. Furthermore, microencapsulated organic contaminants have been successfully used to study the effects of organic contaminants on the growth rate of both larval and adult mussels $(28,29)$. The success of microencapsulation as a method of exposure is evident from the present study in which mussels accumulated high tissue concentrations of PAHs or PCBs. After 30 days, tissue concentration of total PAHs and PCBs

TABLE 2. Lysosomal labilization period, lipofuscin and neutral lipid content, and peroxisome proliferation in the digestive tissue of Mytilus edulis complex after 6 and 30 days of feeding a microencapsulated model mixture of PAHs or PCBs at an equivalent concentration of $150 \mu \mathrm{g} \cdot \mathrm{L}^{-1}$ sea-water. The values represent the mean $\pm S D, n=10$. Peroxisome proliferation expressed as the percent $(\%)$ of mussels showing an increase in size and/or number of peroxisomes in each digestive tubule

\begin{tabular}{|c|c|c|c|c|}
\hline Treatment & $\begin{array}{c}\text { Lysosomal } \\
\text { labilization period } \\
(\mathrm{min})\end{array}$ & $\begin{array}{c}\text { Lipofuscin } \\
\text { content } \\
\text { (pixel density) }\end{array}$ & $\begin{array}{c}\text { Neutral lipid } \\
\text { content } \\
\text { (pixel density) }\end{array}$ & $\begin{array}{c}\text { Peroxisome } \\
\text { proliferation } \\
(\%) \\
\end{array}$ \\
\hline \multicolumn{5}{|l|}{6 Days } \\
\hline Algal control & $20 \pm 8.0$ & $63 \pm 10$ & $38 \pm 10$ & 70 \\
\hline Vehicle control & $27 \pm 4.8^{\mathrm{a}}$ & $54 \pm 16$ & $26 \pm 5^{a}$ & $30^{\mathrm{a}}$ \\
\hline PAHs & $4.7 \pm 3.8^{\mathrm{b}}$ & — $^{c}$ & $44 \pm 7^{b}$ & $100^{\mathrm{b}}$ \\
\hline PCBs & $18 \pm 5.4^{b}$ & $97 \pm 36^{b}$ & $34 \pm 6$ & 60 \\
\hline \multicolumn{5}{|l|}{30 Days } \\
\hline Algal control & $20 \pm 1.6$ & $63 \pm 17$ & $40 \pm 8$ & 90 \\
\hline Vehicle control & $16 \pm 7.3$ & $76 \pm 14$ & $64 \pm 18^{a}$ & $20^{a}$ \\
\hline PAHs & $4.4 \pm 3.9^{b}$ & $120 \pm 21^{b}$ & $60 \pm 11$ & $80^{\mathrm{b}}$ \\
\hline PCBs & $11 \pm 9.1$ & $76 \pm 26$ & $77 \pm 18$ & 20 \\
\hline
\end{tabular}

${ }^{a}$ Indicates value for vehicle control significantly different than corresponding value for algal control mussel $(p \leq 0.05)$.

${ }^{b}$ Indicates significantly different than corresponding value for vehicle control $(p \leq 0.05)$.

cSamples lost and not analyzed. 

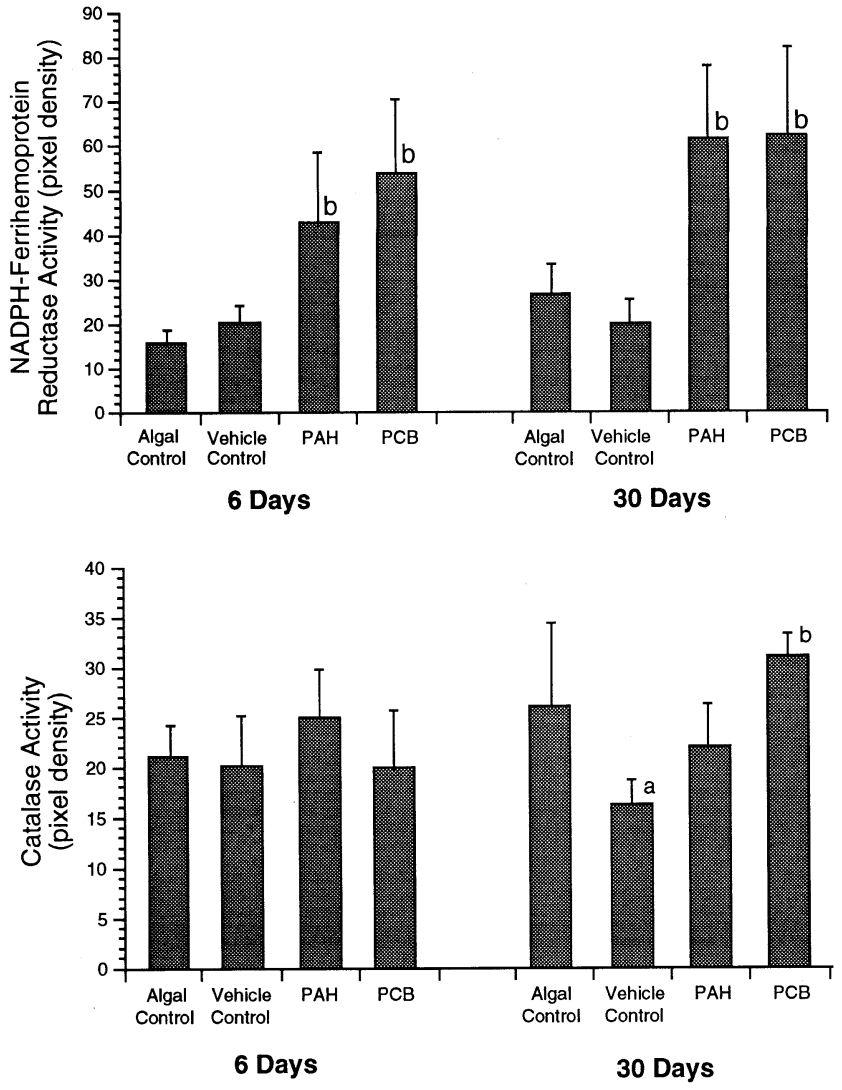

FIG. 1. Activities of NADPH-ferrihemoprotein reductase (NFR) and Catalase (CAT) in the digestive tissue of Mytilus edulis complex after 6 and 30 days of feeding a microencapsulated model mixture of PAHs or PCBs at an equivalent concentration of $150 \mu \mathrm{g} \cdot \mathrm{L}^{-1}$ sea-water. The values repre-

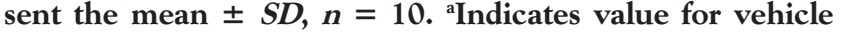
control significantly different than corresponding value for algal control mussel $(p \leq 0.05)$. 'Indicates significantly different than corresponding value for vehicle control ( $p \leq$ $0.05)$.

increased by 76 times and 5 times, respectively, compared to the tissue concentration of mussels exposed for 6 days to PAHs or PCBs.

The bioaccumulation of different PAHs in the tissue of mussels was dissimilar to the proportions mussels were fed. Even though mussels were exposed to microencapsulated PAHs containing a higher proportion of phenanthrene relative to fluoranthene (in a ratio of 5 to 4), a differential accumulation of phenanthrene and fluoranthene was observed in the tissue in a ratio of 5 to 8 after 6 days and 4 to 9 after 30 days. This may be caused by a difference in bioavailability or bioaccumulation from the microencapsulated material fed to the mussels. Meador et al. (20) found that the bioaccumulation factor for fluoranthene was much higher than for phenanthrene in two invertebrate species, a polychaete worm (Armandia brevis), and an amphipod (Rhepoxynius abronius), exposed to field-contaminated sediments, support-
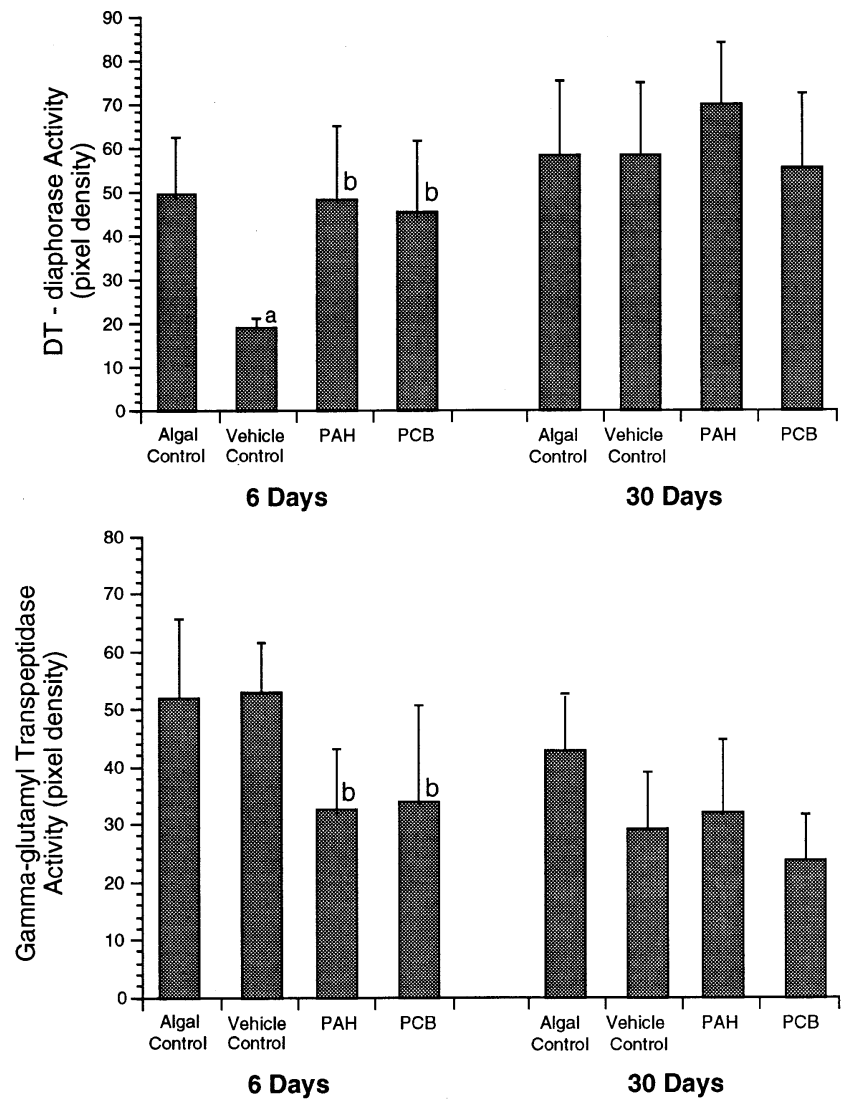

FIG. 2. Activities of DT-diaphorase (DTD) and $\gamma$-glutamyl transpeptidase (GGT) in the digestive tissue of Mytilus edulis complex after 6 and 30 days of feeding a microencapsulated model mixture of PAHs or PCBs at an equivalent concentration of $150 \mu \mathrm{g} \cdot \mathrm{L}^{-1}$ sea water. The values represent the mean

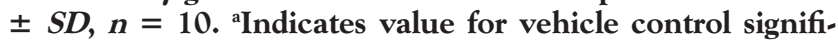
cantly different than corresponding value for algal control mussel $(p \leq 0.05)$. ${ }^{b}$ Indicates significantly different than corresponding value for vehicle control $(p \leq 0.05)$.

ing the findings of higher tissue concentrations of fluoranthene relative to phenanthrene in invertebrate tissues. It is also possible that even with the limited biotransformation capability in mussels, the phenanthrene accumulated in the tissue was preferentially metabolized to a greater extent than fluoranthene. The observed differential accumulation of PAHs in our study is also consistent with the observed concentration of PAHs in naturally-exposed mussels sampled from urban environments. For example, concentrations of the higher molecular weight fluoranthene were greater in comparison to the concentrations of the lower molecular weight phenanthrene in the tissue of M. edulis collected from nine sites in Puget Sound (13). A similar trend was also reported in six species of mulluscs collected from waters around Newfoundland, Canada (10).

Alterations in subcellular structures such as lysosomal membrane stability and lipofuscin content were particularly 
responsive to PAH exposure. Earlier studies have shown that PAHs such as phenanthrene can induce dose-dependent lysosomal destabilization in the digestive tissue of bivalves and trigger the accumulation of lipofuscin, a product of peroxidative reactions on autophagocytosed lipoprotein membranes $(4,21,22,24,30)$. An increased incidence of fatty acid degeneration and the associated lysosomal accumulation of unsaturated neutral lipids has also been reported in the digestive tissue of mussels exposed to contaminants $(13,15,21)$. In the present study, a significant increase in NL content was observed in mussels exposed for 6 days to PAHs but not after 30 days of exposure, with respect to the vehicle control mussels. The inability to identify a significant increase in NL content after 30 days of exposure to PAHs was primarily due to NL concentrations observed in mussels exposed to corn oil (vehicle) for 30 days being significantly higher than the NL content of mussels fed algae only. Corn oil may effect the fatty acid metabolism of mussels and this might have contributed to the significant increase in the NL content in the digestive tissue of vehicle control mussels after 30 days. This may have masked the effect of PAH exposure on the NL content in the digestive tissue.

Although LP and LF content in the digestive tissue of mussels exposed to PCBs were significantly decreased and increased, respectively, after 6 days, significant effects in these parameters were not observed after 30 days of exposure, even though the PCB tissue burden increased during this period. Based on these observations, PCBs do not appear to affect these particular digestive tissue constituents or functions in mussels after dietary exposure, indicating that LP, LF, and NL are primarily responsive to PAHs in the blue mussel at the concentrations achieved in this study.

NADPH-ferrihemoprotein reductase activity was found to be a sensitive indicator of the toxic effects of both PAHs and PCBs whereas CAT activity was significantly increased after exposure to PCBs only. These observations are consistent with previous data from both field and experimental investigations $(11,14,18,21)$. In this study, an approximate $35 \%$ increase in CAT activity was observed in mussels receiving $\mathrm{PAHs}$ relative to levels in mussels receiving corn oil only. Although PAHs have been reported to increase CAT activity, the changes are found to be nonsignificant, such as in ours and other studies (17), or in association with complex PAH mixtures which include other unspecified contaminants (7). The co-occurrance of chemical contaminants makes it difficult to attribute causal relationships to specific chemicals. Even though PAHs are suspected of inducing CAT activity, studies have yet to validate this possibility.

In the present study, significant increase in the activities of DTD and suppression in the activities of GGT were observed only after short term exposure (6 days) to PAHs or PCBs, but not after 30 days of exposure to these contaminants. Organic contaminants such as PAHs induce the ac- tivities of DTD, an antioxidant enzyme (16), and suppress the activities of GGT, a participant in phase II metabolism of xenobiotics (9), in the digestive tissue of mussels $(7,19)$. However, in our previous field investigation, significant increases in the activity of DTD were found only in mussels collected from two highly contaminated sites and no relationship between chemical contaminant body burden and GGT activity were identified (14). Based on these observation, it is not clear if the lack of consistent changes in DTD and GGT activities to either PAH or PCB exposure is due to a lack of a causal relationship or because of interference by corn oil on the activities of these particular enzymes. The results of the present study showed that corn oil (vehicle) appears to exhibit a toxic response in mussels, which is evident from the observed lysosomal membrane dysfunction, increase in NL content, and suppressed activity of GGT in vehicle control mussels compared to mussels receiving the algal diet only. Administering corn oil appears to have masked some of the toxic effects of both PAHs and PCBs in the digestive tissue of mussels, especially after 30 days of exposure, particularly with respect to GGT activity in the digestive tissue. In contrast, DTD activity was significantly increased after 6 days of exposure to both PAHs and PCBs, which was evident primarily as a result of suppressed DTD activity in the vehicle control mussels. No difference in DTD activity in algal control mussels was observed after 6 and 30 days of the experiment and no difference was observed between algal control and vehicle control mussels after the 30-day holding period, indicating that the changes observed in DTD activity after 6 days were not a result of exposure to PAHs or PCBs.

Increased peroxisome proliferation was observed in the digestive tissue of mussels exposed to PAHs. The increase of CAT activity concomitant with the increase in number and size of peroxisomes of the digestive tissue of mussels exposed to PAHs suggests peroxisome proliferation. Our previous field investigations also revealed similar changes in the digestive tissue of mussels collected from urban-associated contaminated sites compared to mussels from the reference sites (14). The observed high level of PP in mussels receiving only a commercially-available concentrated and preserved algal diet, however, is difficult to explain. During this study all mussels in the exposure system were fed with preserved algae consisting of $T$. pseudonana. It is possible that the algal food supplied to the mussels contained an ingredient(s) that was a peroxisome proliferator. However, in the presence of corn oil as a carrier, this induction of PP was apparently suppressed. Nutritional conditions have also been shown to cause PP in other animals (25). Further studies will need to be conducted to find a food supply that does not induce peroxisome proliferation in mussels.

The results of the present study clearly show that NFR activity is a sensitive indicator of exposure to PAHs and PCBs. Catalase activity appears to be a indicator of PCB exposure, whereas structural parameters such as the lyso- 
somal membrane labilization period, lipofuscin and neutral lipid content, and peroxisome proliferation were relatively specific to exposure to PAHs. In our previous field study we reported relationships between the cytochemical changes in the digestive tissue (lysosomal dysfunction, induction of selected detoxifying enzymes and peroxisome proliferation) with the tissue burden of both PAHs and PCBs in indigenous populations of M. edulis collected from Puget Sound $(13,14)$. The results of the present study support the findings of our field observations and suggests that the cytochemical responses in the digestive tissue of indigenous mussels from urban areas were a result of exposure to PAHs and PCBs. Based on the magnitude and the suite of cytochemical and cytological responses that responded in the field studies and the laboratory studies, PAHs appear to be a causal factor for the responses observed in mussels from urban marine habitats in Puget Sound.

P.K.K. is thankful to the Department of Biotechnology, Government of India, New Delhi for awarding a "Biotechnology Overseas Associateship" for conducting this study. The authors are thankful to the following members of the Environmental Conservation Division: Robert G. Snider, Dave Misitano, and Anna Kagley for help in sample collection and experimental exposure study: Dr. Sin-Lam Chan, Don Brown for overseeing the timely completion and quality control of chemical analysis of tissue samples from the exposure study and Dr. Laura Inouye and Paul Olson for critical reviews of the manuscript.

\section{References}

1. Addison, R.F.; Clarke, K.R. The IOC/GEEP Bermuda Workshop. J. Exp. Mar. Biol. Ecol. 138:1-8;1990.

2. Anderson, J.W.; Kiesser, S.L.; Blaylock, J.W. The cumulative effects of petroleum hydrocarbons on marine crustaceans during constant exposure. Rapp. P.-V. Reun. Cons. Int. Explor. Mer. 179:62-70;1980.

3. Angermuller, S.; Fahimi, H.D. Selective cytochemical localization of peroxidase, cytochrome oxidase, and catalase in rat liver with 3,3'diamino-bezenzidine. Histochemistry 71:33-44; 1981.

4. Axiak, V.; George, J.J.; Moore, M.N. Petroleum hydrocarbons in the marine bivalve Venus verrucosa: Accumulation and cellular responses. Mar. Biol. 97:225-230;1988.

5. Bayne, B.L. Measuring the biological effect of pollution: the mussel watch approach. Water Sci. Tech. 21:1089-1100; 1989.

6. Bayne, B.L.; Clarke, K.R.; Gray, G.S. Biological effects of pollutants: The results of a practical workshop. Mar. Ecol. Prog. Ser. 46:1-278;1988.

7. Cajaraville, M.P.; Uranga, J.A.; Angulo, E. Comparative effects of the water-accommodated fraction of three oils on mussels. III. Quantitative histochemistry of enzymes related to detoxification metabolism. Comp. Biochem. Physiol. 103C: 369-377;1992.

8. Green, B.K.; Schleicher, L. Microscopic capsules containing oil. U. S. Patent 2800 457, July 23, 1957. Chem. Abst. 51: $15842 ; 1957$.

9. Hanigan, M.H.; Pitot, H.C. Gamma-glutamyl transpeptidase - its role in hepatocarcinogenesis. Carcinogenesis 6: 165-172;1985.

10. Hellou, J.; Upshall, C.; Payne, J.F.; Naidu, S.; Paranjape, M.A. Total unsaturated compounds and polycyclic aromatic hydro- carbons in molluscs collected from waters around Newfoundland. Arch. Environ. Contam. Toxicol. 24:249-257;1993.

11. Kirchin, M.A.; Wiseman, A.; Livingstone, D.R. Seasonal and sex variation in the mixed-function oxygenase system of digestive gland microsomes of the common musssel, Mytilus edulis L. Comp. Biochem. Physiol. 101C:81-91;1992.

12. Krahn, M.M.; Moore, L.K.; Bogar, R.G.; Wigrens, C.A.; Chan, S-L.; Brown, D.W. High performance liquid chromatographic methods for isolating organic contaminants from tissue and sediment extracts. J. Chromatogr. 437:161-175;1988.

13. Krishnakumar, P.K.; Casillas, E.; Varanasi, U. Effects of environmental contaminants on the health of Mytilus edulis from Puget Sound, Washington, USA. I. Cytochemical measures of lysosomal responses in the digestive cells using automatic image analysis. Mar. Ecol. Prog. Ser. 106:249-261;1994.

14. Krishnakumar, P.K.; Casillas, E.; Varanasi, U. Effects of environmental contaminants on the health of Mytilus edulis from Puget Sound, Washington, USA. II. Cytochemical detection of subcellular changes in the digestive cells. Mar. Biol. 124: 251-259;1995.

15. Leavitt, D.F.; Lancaster, M.A.; Lancaster, A.S.; Capuzzo, J.M. Changes in the biochemical composition of a subtropical bivalve Arca zebra, in response to contaminant gradients in Bermuda. J. Exp. Mar. Biol. Ecol. 138:85-98;1990.

16. Lind, C.; Hochstein, P.; Ernster, L. DT-diaphorase as a quinone reductase: A cellular control device against semiquinone and superoxide radical formation. Arch. Biochem. Biophys. 216:175-185;1982.

17. Livingstone, D.R.; Garcia Martinez, P.; Michel, X.; Narbonne, J.F.; O'Hara, S.; Ribera, D.; Winston, G.W. Oxyradical production as a pollution-mediated mechanism of toxicity in the common mussel, Mytilus edulis L. and other molluscs. Funct. Ecol. 4:415-424;1990.

18. Livingstone, D.R.; Lips, F.; Martinez, P.G.; Pipe, R.K. Antioxidant enzymes in the digestive gland of the common mussel Mytilus edulis L. Mar. Biol. 112:265-276;1992.

19. Livingstone, D.R.; Martinez, P.G.; Winston, G.W. Menadione-stimulated oxyradical formation in the digestive gland microsomes of the common mussels Mytilus edulis L. Aquat. Toxicol. 15:213-236;1989.

20. Meador, J.P.; Casillas, E.; Sloan, C.A.; Varanasi, U. Comparative bioaccumulation of polycyclic aromatic hydrocarbons from sediment by two infaunal invertebrates. Mar. Ecol. Prog. Ser. 123:107-124;1995.

21. Moore, M.N. Cytochemical responses of the lysosomal system and NADPH-ferrihemoprotein reductase in molluscan digestive cells to environmental and experimental exposure to xenobiotics. Mar. Ecol. Prog. Ser. 46:81-89;1988.

22. Nott, J.; Moore, M.N. Effects of polycyclic aromatic hydrocarbons on molluscan lysosomes and endoplasmic reticulum. Histochem. J. 19:357-368;1987.

23. O'Connor, T.P. Mussel watch: Recent trends in coastal environmental quality. Silver Spring, MD: National Oceanic and Atmospheric Administration; 1992.

24. Pipe, R.K.; Moore, M.N. An ultrastructural study on the effects of phenanthrene on lysosomal membranes and distribution of the lysosomal enzyme $\beta$-glucuronidase in digestive cells of the periwinkle Littorina littorea. Aquat. Toxicol. 8:65-76; 1986.

25. Reddy, J.K.; Lalwani, N.D. Carcinogenesis by hepatic peroxisome proliferators: Evaluation of risk of hypolipidemic drugs and industrial plasticizers to humans. CRC Critical Rev. Toxicol. 12:1-58;1983.

26. Sloan, C.A.; Adams, N.G.; Pearce, R.W.; Brown, D.W.; Chan, S-L. Northwest Fisheries Science Center analytical procedures. In: Laurenstein, G.G.; Cantillo, A.Y. (eds). Sam- 
pling and Analytical Methods of the National Status and Trends Program-National Benthic Surveillance and Mussel Watch Projects 1984-1992, Vol. IV, Cohesive Descriptions of Trace Organic Analytical Methods. NOAA Tech, Mem. NOS/ORCA 71. 1993:53-97.

27. Stebbing, A.R.D.; Dethlefsen, V. Introduction to the Bremerhaven workshop on biological effects of contaminants. Mar. Ecol. Prog. Ser. 91:1-8;1992.

28. Stromgren, T.; Nielson, M.V. Spawning frequency, growth and mortality of Mytilus edulis larvae exposed to copper and diesel oil. Aquat. Toxicol. 21:171-180;1991.

29. Stromgren, T.; Nielson, M.V.; Ueland, K. Short-term effects of microencapsulated hydrocarbons on shell growth of Mytilus edulis. Mar. Biol. 91:33-39;1986.

30. Viarengo, A.; Canesi, L.; Pertica, M.; Livingstone, D.R. Seasonal variations in the antioxidant defense system and lipid peroxidation of the digestive gland of mussels. Comp. Biochem. Physiol. 110C:187-190;1991. 